DOI: https://doi.org/10.47405/mjssh.v6i1.630

\begin{tabular}{|c|c|}
\hline 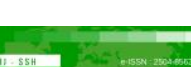 & Malaysian Journal of Social Sciences and Humanities (MJSSH) \\
\hline Malaysian Journal of & Volume 6, Issue 1, January 2021 \\
\hline (MJ-ssH) & e-ISSN : 2504-8562 \\
\hline & $\begin{array}{l}\text { Journal home page: } \\
\text { www.msocialsciences.com }\end{array}$ \\
\hline
\end{tabular}

\title{
Zakah Distribution for The Purpose of Capital Assistance at Zakah Institutions in Malaysia: An Exploratory Study
}

\author{
Noor Fazni Binti Harun'1, Asmak Binti Ab Rahman'1 \\ ${ }^{1}$ Department of Syariah and Economics, Academy of Islamic Studies, University of Malaya (UM) \\ Correspondence: Noor Fazni Binti Harun (fazniharun18@gmail.com)
}

\begin{abstract}
As prescribed by shari'ah, zakah is distributed to eight (8) groups of asnaf. There are different mechanisms in Malaysia to distribute zakah, such as financial support for living, education, medical, et cetera. One of the financial supports from zakah is to motivate the beneficiary of zakah by supplying zakah fund for business purposes. This study will explore the practise of capital assistance among zakah institutions in Malaysia. The information for this research was gathered through interviews conducted between July and September 2019. The findings indicate that, out of fourteen (14) states in Malaysia, only one state does not include zakah for business purposes, which is Sarawak or Tabung Baitulmal Sarawak.
\end{abstract}

Keywords: asnaf, zakah institutions, zakah capital assistance, zakah for business purposes

\section{Introduction}

Zakah refers to the obligatory distribution or rendering of riches from economically stable Muslims within an existing society to benefit certain groups as listed in the Holy Qur'an such as the poor, the needy, etc. (Al-Qardawi, 2000). The maqasid shari'ah prescribes the distribution of zakah accordingly as stated in the Holy Qur'an. i.e. to alleviate poverty and redistribute wealth in order to minimize the gap between the wealthy and the poor. Islam pays great attention to zakah since the word zakah is mentioned fifty-eight (58) times in the Holy Qur'an, i.e thirty-two (32) times in isolation and twentysix (26) times in conjunction with solah (Abdullah \& Mahyuddin, 2011).

Zakah is the third pillar of Islam, representing not only religious destinations but also having socioeconomic goals such as the promotion of economic growth and competitiveness, the fulfilment of utilisation needs, and the equal distribution of resources (Azhana \& Abd Halim, 2012). It is imposed at 2.5 per cent on a Muslim's wealth that exceeds a certain level (nisab) and is held through a lunar year (haul). In order to administer zakah, the Muslim community is obliged to set up a zakah institution to collect zakah from rich Muslims within the society and to distribute it to the beneficiaries who are the deserving poor and needy.

\section{Literature Review}

The Roles of Zakah Institutions in Economic Development 
Malaysia's economic growth declined from 4.8\% in 2018 to $4.5 \%$ in 2019 (Focus Malaysia, 2019) even though it was forecasted to grow at 5.3 percent. Whether or not economic growth has achieved its goal, the authorities still need to step up reforms to improve productivity and increase the standard of living for its 32 million people. Malaysia will effectively continue its efforts to improve the living standard of households, especially to 40 percent of the low-income group ${ }^{1}$ or B40 group (Budget Tax Articles, 2019). According to the budget figures, some 2.7 million households in Malaysia are in the B40 group (Islamic Voice, 2018). However, there has been an increased of 2.91 millions households in this group in the year 2019 (Department of Statistics Malaysia, 2019).

In order to increase the standard of living for 32 million people in Malaysia, $40 \%$ of whom are listed as low per capita incomes, the government is obliged to improve its economic policy, particularly in creating more job opportunities (to reduce unemployment) and by fostering entrepreneurial spirit among citizens in order to increase the number of entrepreneurs.

In the Eleventh Malaysian Plan or Rancangan Malaysia Kesebelas (RMK-11), entrepreneurship is one of the sectors that the government highlighted, especially involving adolescents in the business sector (Rancangan Malaysia Kesebelas, 2015). This responsibility should not be borne by the government alone, but supposedly shared with other entities /agencies /organisations in this country, such as zakah institutions.

In order to achieve all these goals, that is to reduce poverty, increase efficiency and increase the standard of living of people, zakah institutions play their part as a 'small co-driver' for the government to reduce the level of poverty in Malaysia. Effective management of zakah funds and implementation of programmes and activities can produce a greater number of successful asnaf entrepreneurs.

\section{The Establishmentof Zakah Institutions in Malaysia}

The administration of zakah is under the jurisdiction of the state; under the patronage of HRH Yang Di-Pertuan Agong, for the Federal Territory, while under the Sultan or Raja for other states in Malaysia. This responsibility is held by Majlis Agama Islam Negeri (MAIN) except Kedah on behalf of the Majesty which has a special institution for zakah, namely Jabatan Zakat Kedah ${ }^{2}$ which is independent of the MAIN (Azman, Alias \& Syed Mohd, 2012).

Due to the demand for zakah collection and distribution activities more efficiently and effectively, there are a number of zakah institutions that have taken the initiative to corporatize their collection and distribution activities (Norazlina \& Abdul Rahim, 2011). This is done by regulating a body, which acts as a subsidiary of Majlis Agama Islam Negeri (MAIN) or the State Islamic Religious Council (SIRC) to fulfill the obligations referred to above (Azman, Alias \& Syed Mohd, 2012).

At present, only seven institutions are implementing the idea of corporatization (Hairunnizam, 2014). These institutions include Pusat Pungutan Zakat Wilayah Persekutuan (PPZ) in January 1991, Lembaga Zakat Selangor (LZS) ${ }^{3}$ in 1994; Zakat Pulau Pinang (ZPP) 4 in June 1994, Pusat Kutipan Zakat Pahang (PKZ) in 1995 and Pusat Zakat Melaka (PZM) in 2001. Tabung Baitulmal Sarawak was

\footnotetext{
${ }^{1}$ Survey findings also showed that income threshold for the B40 group in 2019 comprising 2.91 million households was RM4,849. The M40 group's income threshold involving 2.91 million households was between RM4,850 to RM10,959. In addition, there were 1.46 million households in T20 group with income more than RM10,960. In terms of income distribution, the T20 constituted 46.8 per cent of total household income as compared to 46.2 per cent in 2016. Moreover, the M40 group had 37.2 per cent, while the B40 only covered 16.0 per cent of total income, decreased from 16.4 per cent in 2016.

${ }^{2}$ Jabatan Zakat Kedah or newly known as Lembaga Zakah Negeri Kedah is the only one zakah institutions that is independent of the administration of the State Islamic Religious Council. In the year 2015, the Kedah Darul Aman State Zakat Board (LZNK) enactment was introduced to replace the Kedah Darul Aman State Zakat Department (JZNK) enactment. With this enactment, LZNK administered on behalf of His Majesty.

${ }^{3}$ Lembaga Zakat Selangor was initially known as MAIS Zakat Sdn Bhd. In 1997, the name was changed to Pusat Zakat Selangor, and finally renamed as Lembaga Zakat Selangor in 2006

${ }^{4}$ formerly known as Pusat Urus Zakat Pulau Pinang
} 
corporatized in 2001, followed by Pusat Zakat Sabah ${ }^{5}$ at the end of 2004. Previously, Pusat Zakat Negeri Sembilan (PZNS) also corporatized its collection in 1998, but with effect from 1 May 2019, Perbadanan Baitulmal Negeri Sembilan (PBMalNS) was formed by the PZNS joint venture with the Baitulmal Negeri Sembilan, and now both collection and distribution are handled by PBMalNS.

In terms of distribution, the councils in the states of Selangor (LZS) in year 1998, Pulau Pinang (Zakat Pulau Pinang) in year 1994 have corporatized their method of disbursement. In Johor, the management of zakah remains under the administration of the SIRC known as Majlis Agama Islam Negeri Johor (Che Yaacob et al, 2013). Other states like Terengganu (Majlis Agama Islam and Adat Melayu Terengganu-MAIDAM), Sabah (Majlis Ugama Islam Sabah-MUIS), Perak (Majlis Agama Islam dan 'Adat Melayu Perak-MAIPk), Kelantan (Majlis Agama Islam dan Adat Istiadat Melayu KelantanMAIK) and Perlis (Majlis Agama Islam dan Adat Istiadat Melayu Perlis-MAIPs), zakah continues to be collected and distributed under the management of the SIRC. This means that only Selangor, Penang, Sarawak and Sabah have fully corporatized both the collection and distribution functions (Norazlina \& Abdul Rahim, 2011). Below is the table that can simplify the establishment of the zakah institutions in Malaysia.

Table 1: Four Different Forms of Collection and Distribution Activities of Zakah Institutions in Malaysia

\begin{tabular}{|c|c|c|}
\hline $\begin{array}{l}\text { Establishment of } \\
\text { institutions }\end{array}$ & Name of Zakah Institutions & Remarks \\
\hline UnderZakat Enactment & $\begin{array}{l}\text { 1. Lembaga ZakatNegeri Kedah } \\
\text { 2. Tabung Baitulmal Sarawak }\end{array}$ & $\begin{array}{l}\text { Kedah Zakat Enactment } \\
1955^{6} \\
\text { Sarawak Islamic Council } \\
\text { (Corporation) } \\
\text { Amendment } 1984\end{array}$ \\
\hline $\begin{array}{l}\text { Under the sta te } \\
\text { a dministration of Islamic } \\
\text { law enactment }\end{array}$ & $\begin{array}{l}\text { 3. Lembaga Zakat Sela ngo } \\
\text { 4. Zakat Pulau Pinang }\end{array}$ & $\begin{array}{l}\text { Trustee (Corporation) } \\
\text { Act } 1952 \\
\text { Companies Act } 1965 .\end{array}$ \\
\hline $\begin{array}{l}\text { Under an Act or State } \\
\text { a dministration of Islamic } \\
\text { Law Enactment with a } \\
\text { duty to collect zakah only }\end{array}$ & $\begin{array}{l}\text { 5. Pusat Pungutan Zakat to Majlis Agama Islam } \\
\text { WilayahPersekutuan } \\
\text { 6. Zakat Melaka to Majlis Agama Islam Melaka } \\
\text { 7. Pusat Zakat Negeri Sembilan to Majlis } \\
\text { Agama Islam NegeriSembilan }{ }^{7} \\
\text { 8. Pusat Kutipan Zakat Pahang to Majlis Ugama } \\
\text { Islam dan 'Adat Resam Melayu Pahang }\end{array}$ & $\begin{array}{l}\text { All collections would be } \\
\text { channeled to MAIN } \\
\text { which distributes zakah } \\
\text { collected to therightful } \\
\text { beneficiaries }\end{array}$ \\
\hline $\begin{array}{l}\text { Executed under Majlis } \\
\text { Agama Islam Negeri } \\
\text { (MAIN) }\end{array}$ & $\begin{array}{l}\text { 9. Majlis Agama Islam Negeri Johor; } \\
\text { 10. Majlis Agama Islam dan Adat Istiadat } \\
\text { Melayu Perlis; } \\
\text { 11. Majlis Agama Islam dan 'Adat Melayu Perak; } \\
\text { 12. Majlis Agama Islam dan Adat Istiadat } \\
\text { MelayuKelantan; } \\
\text { 13. Majlis Agama Islam dan Adat Melayu } \\
\text { Terengganu } \\
\text { 14. Majlis Ugama Islam Sabah. }\end{array}$ & $\begin{array}{l}\text { Collection and } \\
\text { distribution of zakah is } \\
\text { executed by MAIN } \\
\text { through its own unit or } \\
\text { department of Baitulmal } \\
\text { or zakah centres }\end{array}$ \\
\hline
\end{tabular}

Modified from Azman, Alias \& Syed Mohd Najib (2012)

\footnotetext{
${ }^{5}$ The name of the 'Bahagian Baitulmal dan Zakat' was changed to 'Bahagian Zakat dan Fitrah' following the incorporation of Baitulmal into Perbadanan Baitulmal Negeri Sabah. In year 2007, Bahagian Zakat dan Fitrah was rebranding by highlighting the commercial name "Pusat Zakat Sabah". Despite this, it is still remain as one of the divisions under the MUIS administrative structure.

${ }^{6}$ Lembaga Zakat Negeri Kedah Darul Aman Enactment, 2015 was introduced to replace the Kedah Darul Aman State Zakat Department (JZNK) Enactment.

${ }^{7}$ Nevertheless, this process has ended on 30th of April 2019 because effective $1^{\text {st }}$ May 2019, both collection and distribution activities are handled by Perbadanan Baitulmal Negeri Sembilan, but the administration is still under the Majlis Agama Islam Negeri Sembilan.
} 


\title{
The Zakah Institutions and Disbursement Process
}

The State Islamic Religious Council (SIRC) or Majlis Agama Islam Negeri (MAIN) directs all zakah institutions in Malaysia to be responsible for the collection and disbursement of zakah funds. Each of these SIRCs is organized at the national level by a government department called JAWHAR or the Department of Endowment (Awqaf), Alm (Zakah) and Pilgrim (Hajj). The special task of JAWHAR, which was established on $27^{\text {th }}$ March 2004, is to organize and promote these zakah institutions to increase the efficiency and effectiveness of SIRCs (Sherliza, Raedah \& Mazlina, 2017).

The zakah goal is for the eight (8) categories of asnaf that are entitled to receive zakah, as mentioned in the Holy Qur'an:

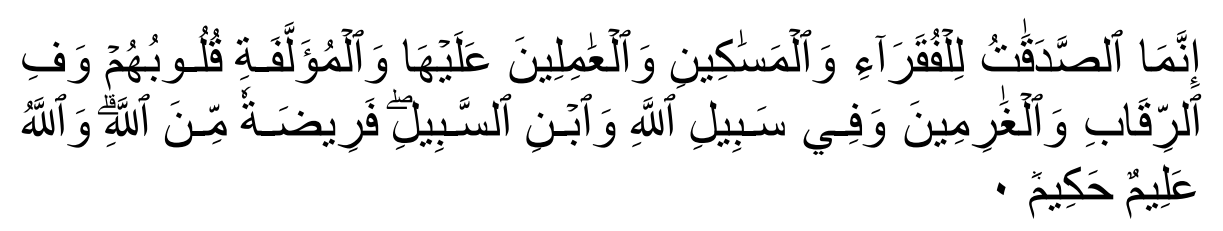

(at-Taubah, verse: 60)

\begin{abstract}
"Alms are for the poor and the needy, and those who employed to administer the (funds); for those whose hearts have been (recently) reconciled (to Truth); for those in bondage and in debt; in the cause of Allah, and for the wayfarer; (thus is it) ordained by Allah, and Allah is full of knowledge and wisdom."
\end{abstract}

In accordance with this Holy Qur' an verse, those who are eligible for zakah are poor (fuqara') whose income does not reach half the requirements; needy (masakin) whose income slightly exceeds half the need; 'amil, the person who administers the zakah, muallaf the one who is consoled to convert to Islam; ar-Riqab: a freed slave; al-Gharimin: those under debt for the way of Allah; Fisabilillah: those who fight against the hand of God and ibn-Sabil: pilgrims who lose their supplies on the journey of allowed syara' (Makalah Panduan Zakat, Lembaga Zakat Negeri Kedah Darul Aman).

The zakah institution acts as an intermediary between zakah payers and zakah recipients. It plays an important role in the efficient collection and distribution of zakah (Hairunnizam, Sanep \& Radiah, 2009). It must ensure that the poor achieves their minimum means of survival, but for the sake of enabling them to get out of the poverty circle, start-up capital assistance should be provided to the asnaf who wants to be an entrepreneur.

Zakah disbursement to an asnaf who wants to be an entrepreneur can solve the problems of poverty. In the sense of the individual, it will enable the asnaf to step away from the status of mustahiq (who receives zakah) and to be muzakki (who pays zakah) with the hope to bring them into economic freedom. In the sense of ummah, setting aside the proportion of those in need purifies their possessions, and it is like pruning plants, this reduces the balance and promotes development (Islamic Voice, 2018).

In terms of distribution, the zakah institutions play an important role in complementing the government's efforts to eliminate poverty, while their reach is for indigent Muslims only (Azman, Mohamad \& Syed Najib, 2012). By providing effective distribution to asnaf, in particular to productive zakah recipients (Hashim \& Syed Musa, 2019), zakah institutions are able to help the government to build additional numbers of entrepreneurs across the country.

Zakah institution is obliged to manage the method of disbursement of the zakah. One way to ensure asnafs to be autonomous is to provide capital assistance for business purposes. Establishing this capital assistance is intended to enable and benefit asnafs to be self-reliant and self-sufficient, as well as to improve their self-esteem. Hypothetically, asnafs who are effectively immersed in a small enterprise 
through this capital assistance are helping themselves and their families to improve their financial condition. This, in fact, is improving and escalating the economy of society. This is a practical attempt to determine the presence and right of zakah according to Islam.

\section{Business Capital Assistance via Zakah Funds}

One of the strategies to help asnafs evade from poverty is by offering zakah in terms of capital assistance. By offering zakah assistance, zakah receivers are encouraged to start a small business to generate income that is considered effective financial assistance, while zakah for subsistence purposes is considered non-productive assistance because it does not generate but only stagnates any attempt to generate income.

Zakah for capital assistance refers to the distribution of zakah funds for asnaf who wish to obtain capital support, whether to start a new business or to sustain their current business. The distribution of zakah through zakah capital is another creation in the approach of zakah disbursement, which is left open and not set in a particular form of distribution (Hashim \& Syed Musa, 2019).

In economics, capital is one of the functions of production. It contains all aids used in the production of consumer goods and services including various kinds of tools, machinery, equipment, plants, warehouses, transport and storage facilities (Mc Connell, Brue \& Flynn, 2018). Capital is used in the ordinary language in the context of money. But when we talk about capital as a factor of production, it would be a mistake to confuse capital with money. The same is true of the zakah contexts, where capital assistance is not provided only in terms of monetary payment; instead zakah institutions provide machinery, tools and production equipment, and much more in order to assist asnaf in the growth of their business.

Zakah capital assistance is a capital aid that is provided to asnaf who meets certain conditions that are used to start or continue their business (Raudha et.al, 2011). It is one of the types of zakah given by the zakah institutions to help asnaf recipients, particularly fuqara' and masakin, stand on their feet and be able to change their economic conditions in order to have a better standard of living.

By using the business capital provided by zakah institutions, asnafs can change their status from the mustahiq to the muzakki, by venturing into a new business. This way, asnafs are able to improve their economic condition; shifting from its current meagre earnings to become an entrepreneur. Muzakki is an individual Muslim or corporate body that is expected to pay zakah while mustahiq is the entity to receive zakah.

\section{Methodology}

This study was organized based on the interview method that has been conducted in all zakah institutions throughout Malaysia, including Sabah and Sarawak through face-to-face meetings, telephone calls and e-mail platforms.

The study which started from July to September 2019 took place between researchers and sixteen (16) zakah officers in Lembaga Zakat Negeri Kedah (LZNK), Lembaga Zakat Selangor (LZS), Majlis Agama Islam Negeri Johor (MAIJ), Majlis Ugama Islam Sabah (MUIS), Majlis Ugama Islam dan 'Adat Resam Melayu Pahang (MUIP), Majlis Agama Islam dan Adat Melayu Terengganu (MAIDAM), Perbadanan Baitulmal Negeri Sembilan (PBMalNS), Majlis Agama Islam dan Adat Istiadat Melayu Perlis (MAIPs), Majlis Agama Islam Wilayah Persekutuan (MAIWP) - consists of three zakah institutions i.e Kuala Lumpur, Putrajaya and Labuan, Zakat Pulau Pinang (ZPP), Majlis Agama Islam Melaka (MAIM), Majlis Agama Islam dan 'Adat Melayu Perak (MAIPk), Majlis Agama Islam dan Adat Istiadat Melayu Kelantan (MAIK) and Tabung Baitulmal Sarawak (TBS). 
Apart from that, this article also uses secondary sources as a reference, namely from books, seminar papers, annual reports, pamphlets, and websites of the Islamic Religious Council in all these states to obtain additional information from the interviews that have been obtained.

\section{Result}

\section{Does Zakah Institutions in Malaysia Give Zakah for Capital Assistance?}

Out of the fourteen (14) zakah institutions in Malaysia, do all institutions engage in the disbursement of zakah for capital assistance?. By interviewing sixteen (16) zakah officers in fourteen (14) zakah institutions (i.e. thirteen (13) states and three (3) Federal Territories (Kuala Lumpur, Putrajaya and Labuan) between July and September 2019, the researcher found that all zakah institutions in Malaysia have business allocations except for Sarawak (Tabung Baitulmal Sarawak). (Note: All three (3) Federal Territories shall be represented by one (1) SIRC). Below is the table that can simplify the findings of this study.

Table 2: Implementation of Zakah for Capital Assistance at all Zakah Institutions in Malaysia

\begin{tabular}{|c|c|c|c|}
\hline $\begin{array}{l}\text { Name of SIRC/ Zakat } \\
\text { Institutions }\end{array}$ & $\begin{array}{l}\text { Unit/ Department/ Subsidiary that } \\
\text { incharged Zakah for Business } \\
\text { Purposes }\end{array}$ & $\begin{array}{l}\text { The } \\
\text { Practice } \\
\text { of Zakah } \\
\text { for } \\
\text { Business } \\
\text { Purposes }\end{array}$ & $\begin{array}{l}\text { Year of } \\
\text { establishment }\end{array}$ \\
\hline $\begin{array}{l}\text { 1. Lembaga Zakat Negeri } \\
\text { Kedah (LZNK) }\end{array}$ & $\begin{array}{c}\text { Unit Pembangunan Ekonomi Asnaf, } \\
\text { Bahagian Pembangunan Asnaf }\end{array}$ & $\sqrt{ }$ & 2005 \\
\hline
\end{tabular}

\section{Tabung Baitulmal} Sarawak (TBS)

- NA- $\quad \times \quad-$ NA-

\begin{tabular}{lcll}
\hline 3. Lembaga Zakat & $\begin{array}{c}\text { Pusat Pembangunan Usahawan Asnaf } \\
\text { Zakat (2012), MAIS ZakatSdn } \\
\text { Selangor(LZS) } \\
\text { Berhad(2013-2017) Teraju Ekonomi } \\
\text { Asnaf, TERAS (2017-now) }\end{array}$ & $\sqrt{ }$ & 1994 \\
& & \\
\hline
\end{tabular}

4. Majlis Agama Islam Wilayah Persekutuan (MAIWP)

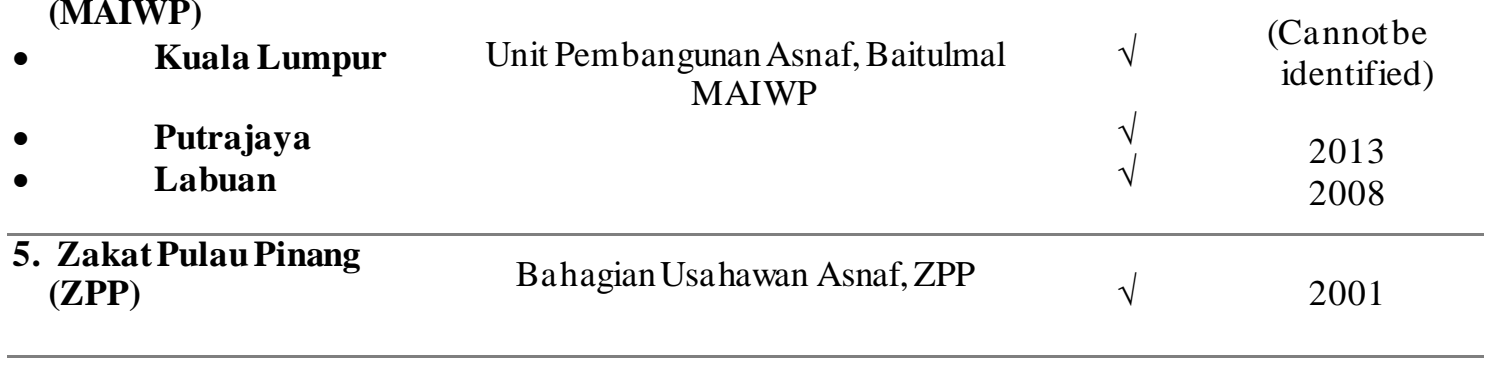

\section{Majlis Agama Islam} Melaka (MAIM)

Bahagian AgihanZakat, MAIM

2009

7. Perbadanan Baitulmal Negeri Sembilan (PBMalNS) 
DOI: https://doi.org/10.47405/mjssh.v6i1.630

\begin{tabular}{lccc}
\hline $\begin{array}{l}\text { 8. Majlis Ugama Islam } \\
\text { Dan Adat Resam } \\
\text { Melayu Pahang (MUIP) }\end{array}$ & Unit Pembangunan Asnaf, MUIP & $\sqrt{ }$ & 2010 \\
\hline $\begin{array}{l}\text { 9. Majlis Agama Islam } \\
\text { Negeri Johor (MAIJ) }\end{array}$ & $\begin{array}{c}\text { Unit Pembangunan Asnaf, Bahagian } \\
\text { Agihan Zakat, MAIJ }\end{array}$ & $\sqrt{ }$ & 2008 \\
\hline $\begin{array}{l}\text { 10.Majlis Agama Islam } \\
\text { dan Adat Melayu Perak } \\
\text { (MAIPk) }\end{array}$ & $\begin{array}{c}\text { Unit Pemerkasaan Ekonomi, Bahagian } \\
\text { Agihan Zakat }\end{array}$ & $\sqrt{ }$ & 2014
\end{tabular}

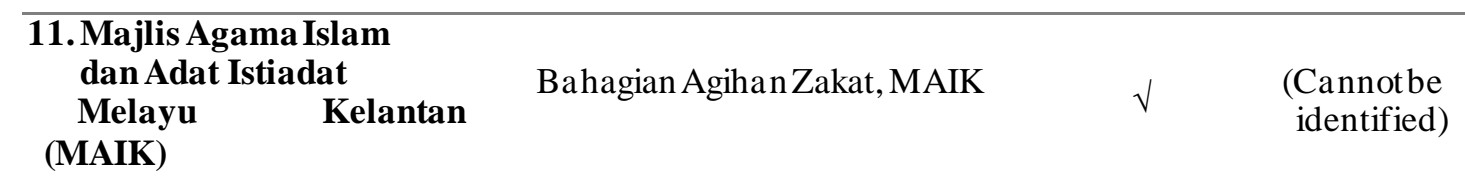

12. Majlis Agama Islam dan Adat Melayu

Terengganu

Bahagian AgihanZakat (Unit

(MAIDAM)

Ekonomidan Keusahawanan), MAIDAM

1957

13. Majlis Agama Islam
dan Adat Istiadat
Melayu Perlis (MAIPs)

Bahagian Agihan Zakat, MAIPs

2010 14. Majlis Ugama Islam
Sabah (MUIS)

Bahagian Zakat dan Fitrah

2014

Source: All inputs came from interview sessions with zakah officers at all zakah institutions in Malaysia

\section{Discussion}

The discussion of this paper focuses on the obligation of the zakah institutions across Malaysia and their role in handling zakah for capital assistance. It can be said that almost all the zakah institutions across Malaysia have made efforts to disburse a certain amount of zakah funds to be used as zakah for business purposes, except for Sarawak (or Tabung Baitulmal Sarawak). Based on the results of the study, it was found that the zakah institution under MAIDAM was the first institution to allow zakah distribution applications in the form of business capital assistance, namely in 1957. This is in accordance with the status of MAIDAM which was the first state to establish a religious council in 1367, based on 'Fasal 4 Tambahan kepada Undang-Undang Bagi Diri Kerajaaan' Terengganu, 1367. Then the implementation of zakah capital assistance disbursement were followed by LZS, MAIWP, LZNK and zakah institutions in other states, except TBS.

All zakah distributions are carried out by the respective zakah distribution divisions. The next study proposal will be formulated by the researcher to identify what are the factors cause the TBS for not disbursing zakah in the form of business capital assistance.

\section{Conclusion}

This study was done to identify which state provides zakah capital assistance to the asnaf group to do business, along with the year of the start to grant this business capital assistance. This is to obtain the basis for conducting further studies related to zakah capital assistance in the states that provide such facilities either in terms of type of distribution, type of business financing provided, amount of financing including methods of selection of asnaf who are truly eligible to be given capital assistance. 
The allocation of zakah capital assistance enables zakah beneficiaries to become zakah payers instead. This is to promote the spirit and passion of entrepreneurship among the asnaf to be asnaf entrepreneurs. The success of this effort depends on the success of the asnafs in immersing themselves in the small business from being mustahiq to muzzaki. This subject matter should be discussed in order to ensure the worthiness of zakah capital assistance. The efforts of zakah institutions do not always guarantee a $100 \%$ success, but the failure factors; more often than not, come from the asnaf entrepreneurs themselves. Certain changes should be made in order to strengthen the legitimacy of the zakah institutions and to ensure that candidates seeking capital assistance achieve their objectives and be successful.This means that the method of distributing zakah to asnaf entrepreneurs must be followed by a proper screening method, as indicated by the zakah officers responsible for selecting the most deserving applicants.

Hashim \& Syed Musa (2019) claimed that, to this extent, there is no formal screening mechanism prior to the rightful disbursement of assistance to asnaf entrepreneurs from zakah institutions. The question posed by Rosbi \& Sanep (2011) is whether the investment is capable of providing a good return or not. Hazlina, Jamaliah \& Sharifah Nurzehan (2012) also highlighted the issue of the identification of eligible asnaf prior to the grant of capital assistance.

With the help of zakah capital assistance, accompanied by the existence of quality screening methods implemented by zakah institutions, eligible asnafs who are truly qualified to venture into businesses can be successful as entrepreneurs and break free from the shackles of poverty. This will ultimately help the government in reducing the poverty rate in the country.

\section{Acknowledgments}

The authors would like to express thanks to Kolej Universiti Poly-Tech MARA, Kuala Lumpur for supporting this study and convey their sincere gratitude to Dr. Norehan binti Hussein for her insightful comments while editing this paper.

This article is modified from a paper entitled "Does Zakah Institutions in Malaysia Give Zakah for Business Purposes", e-Proceedings of the National Islamic Finance Seminar (eSKIK 2020), Lembaga Zakat Negeri Kedah, 28 April -21 May 2020.

\section{References}

Al-Qur'anul Kareem.

Al-Qardawi, Yusuf. (2000). Fiqh al-Zakah, Vol II, English Translation by Monzer Kahf, Jeddah, Scientific Publishing Centre, King Abdul Aziz University.

Azman Abdul Rahman, Mohamad Alias \& Syed Mohd Najib Syed Omar. (2012). Zakat Institution in Malaysia : Problems and Issues. GJAT 2, 1, 35-42.

Abdullah Haji Abd.Ghani \& Mahyudin Haji Abu Bakar. (2011). Towards Achieving the Quality of Life in the Management of Zakat Distribution to the Rightful Recipients (The Poor and Needy). International Journal of Business and Social Science, 2(4), 237-45.

Ahmad Che Yaacob, Safiah Mohamed, Azizah Daut, Normah Ismail, \& Mohd Ali Mohd Don. (2013). Zakat Disbursement via Capital Assistance: A Case Study of Majlis Agama Islam Johor. Journal of Emerging Economies and Islamic Research. https://doi.org/10.1088/17518113/44/8/085201.

Azhana Othman \& Abd Halim Mohd Noor. (2012). Role of Zakat in Minimizing Economic Inequalities among Muslim: A Preliminary Study on Non Recipients of Zakat Fund ( NRZF ). 3rd International Conference of Business and Economic Research: 1209-22.

Hairunnizam Wahid. (2014). Localization of Malaysian Zakat Distribution: Perceptions of Amil and Zakat Recipients. Faculty of Economics and Administration, University of Malaya. 
DOI: https://doi.org/10.47405/mjssh.v6i1.630

Hairunnizam Wahid, Sanep Ahmad \& Radiah Abdul Kader. (2009). Pengagihan Zakat Oleh Institusi Zakat Di Malaysia : Mengapa Masyarakat Islam Tidak Berpuas Hati?’. Jurnal Syariah, 94.

Hashim Ahmad Shiyuti \& Syed Musa Al-Habshi. (2019). An Overview of Asnaf Entrepreneurship Program by Lembaga Zakat Selangor, Malaysia. SSRN Electronic Journal). https://doi.org/10.2139/ssrn.3299107.

Hazlina Abdul Halim, Jamaliah Said \& Sharifah Nurzehan Syed Yusuf. (2012). Individual Characteristics of the Successful Asnaf Entrepreneurs: Opportunities and Solutions for Zakat Organization in Malaysia. International Business and Management, 4(2), 41-49. https://doi.org/10.3968/j.ibm.1923842820120402.1040.

McConnell, C.R, Brue, S.L \& Flynn, S.M (2018). Economics: Principles, Problems and Policies, Mc Graw Hill Education, $21^{\text {st }}$ edition, pg. 9

Norazlina Abd Wahab \& Abdul Rahim Abdul Rahman. (2011a) A Framework to Analyse the Efficiency and Governance of Zakat Institutions. Journal of Islamic Accounting and Business Research, 2(1), 43-62. https://doi.org/10.1108/17590811111129508.

Norazlina Abd Wahab \& Abdul Rahim Abdul Rahman. (2011b). Efficiency of Zakat Institutions In Malaysia: An Application of Data Envelopment Analysis 1. Journal of Economic Cooperation and Development, 33, 95-112.

Sherliza Puat, Raedah Sapingi \& Maslina Ahmad. (2017). Identifying Disclosure Items for Zakat Institutions. Asian Academic Accounting Association.

Rosbi Abdul Rahman \& Sanep Ahmad. (2011). Entrepreneurship Development Strategy for Poor and Needy Recipients on Capital Assistance through Zakat Distribution. Jurnal Pengurusan.

Rancangan Malaysia Kesebelas. (2015). Ucapan Perdana Menteri YAB Dato' Sri Mohd Najib Bin Tun Haji Abdul Razak Semasa Membentangkan Usul Tentang Rancangan Malaysia Kesebelas.

Raudha Md. Ramli, Sanep Ahmad, Hairunnizam Wahid, \& Farrah Munna Harun. (2011). Understanding Asnaf Attitude: Malaysia's Experience in Quest for an Effective Zakat Distribution Programme. In Sustainable Development of Zakat in the Poverty Alleviation and Improvement of Welfare of the Ummah. http://www.ukm.my/hairun/kertas kerja/Paper Raudha et al.pdf.

Sherliza Puat, Raedah Sapingi \& Maslina Ahmad. (2017). Identifying Disclosure Items for Zakat Institutions." Asian Academic Accounting Association. 